\title{
Unfolding additional massive cutback effects of the Native Vegetation Protection Law on Legal Reserves, Brazil
}

\author{
Paulo André Tavares $^{1, *}$, Alice Dantas Brites ${ }^{1}{ }^{\mathbb{D}}$, Gerd Sparovek $^{1}$, Vinícius Guidotti ${ }^{2}$, Felipe Cerignoni ${ }^{2}$, Daniel \\ Aguiar $^{3}$, Jean Paul Metzger 4 , Ricardo Ribeiro Rodrigues ${ }^{5}$, Luis Fernando Guedes Pinto ${ }^{2}$, Kaline de Mello ${ }^{4} \&$ \\ Paulo Guilherme Molin ${ }^{6}$ \\ ${ }^{1}$ Universidade de São Paulo, Departamento de Ciências do Solo, Piracicaba, SP, Brasil. \\ ${ }^{2}$ Instituto de Manejo e Certificação Florestal e Agrícola, Imaflora, Piracicaba, SP, Brasil. \\ ${ }^{3}$ Agrosatélite Geotecnologia Aplicada, Florianópolis, SC, Brasil. \\ ${ }^{4}$ Universidade de São Paulo, Instituto de Biociências, São Paulo, SP, Brasil. \\ ${ }^{5}$ Universidade de São Paulo, Departamento de Ciências Biológicas, Piracicaba, SP, Brasil. \\ ${ }^{6}$ Universidade Federal de São Carlos, Centro de Ciências Naturais, Buri, SP, Brasil. \\ *Corresponding author: Paulo André Tavares.e-mail: patavares@usp.br
}

TAVARES, P.A. BRITES, A.D. SPAROVEK, G. GUIDOTTI, V. CERIGNONI, F. AGUIAR, D. METZGER, J.P.W. RODRIGUES, RICARDO. PINTO, L.F.G. MELLO, K. MOLIN, P. G. Unfolding additional massive cutback effects of the Native Vegetation Protection Law on Legal Reserves, Brazil. Biota Neotropica. 19(4): e20180658. http://dx.doi.org/10.1590/1676-0611-BN-2018-0658

\begin{abstract}
The Native Vegetation Protection Law - 2012 - (NVPL) is the main Brazilian regulation for protecting native vegetation (NV) on private land. The NVPL, currently in the implementation phase, reduced Legal Reserves (LR) requirements compared to its previous version, the 1965's Forest Act (FA), through several legal mechanisms. Among them, Article 68 (Art.68) exempts landholders from LR obligations if NV was converted without offending the legislation in place at the time of the conversion. The technical implementation of Art. 68 is controversial and its effects are still unknown. We developed a model to estimate the effects of Art.68 on LR using São Paulo State (Brazil) as case study. We analyzed former environmental laws to identify key periods in which NV preservation requirements had changed. After, we searched for past spatial data on NV cover with sufficient accuracy for each legal benchmark. Combining legal benchmarks with spatial data, we created two scenarios for Art.68 effects, plus a baseline scenario. The first scenario considered a single legal benchmark, the 1965's FA (scenario "1965"), while the other included the 1989 Cerrado's protection Federal Law as a second benchmark (scenario "1965/89"). The baseline scenario did not include Art.68 effects. Scenario " 1965 " reduced LR deficits in $49 \%$ compared to the baseline scenario, waiving landholders from restoration or offsetting needs in 423 thousand hectares (kha) of NV. Scenario “1965/89" waved 507 kha of NV from restoration needs and represented a 59\% reduction in LR deficit compared to the baseline scenario. The LR reduction by scenario "1965/89" assumed particular importance considering that the additional cutback was concentrated on Cerrado, an already very fragmented and impacted region. Together with reductions from other NVPL rules, the additional effects of Art. 68 unfolded great concerns about the role of $\mathrm{LR}$ as a tool for $\mathrm{NV}$ preservation on private land, threating governmental restoration commitments, and pointing that conservation command and control approaches should be complemented with incentive policies to achieve the desired and committed standards.

Keywords: Native Vegetation, Biodiversity Conservation, New Forest Act, São Paulo State, Environmental Regularization Program.
\end{abstract}

\section{Revelando reduções adicionais de Reserva Legal da Lei de Proteção da Vegetação Nativa, Brasil}

Resumo: A Lei de Proteção da Vegetação Nativa - 2012 - (LPVN) é a principal lei brasileira para proteção da vegetação nativa $(\mathrm{VN})$ em terras privadas. A LPVN, atualmente em fase de implementação, reduziu os requerimentos de Reserva Legal (RL) presentes no Código Florestal (CF) de 1965 através de uma série de mecanismos legais. Entre eles, o Artigo 68 (Art.68) elimina a obrigação de recomposição ou restauração da VN convertida sem violação 
Tavares, P.A. et al.

da lei vigente à época da conversão. O Art.68 é um dos mais controversos mecanismos da LPVN e cujos efeitos ainda não são conhecidos. Nós desenvolvemos um modelo para estimar os efeitos do Art.68 utilizando o estado de São Paulo, Brasil, como estudo de caso. Para isso, levantamos marcos legais nos quais os requerimentos mínimos de preservação da VN foram alterados. Em seguida, levantamos a existência de dados espaciais da cobertura de VN com a precisão necessária para cada marco legal. Combinando os marcos legais com os dados espaciais encontrados, criamos dois cenários incluindo os efeitos do Art.68 e um cenário linha de base para controlar tais efeitos. O primeiro cenário considerou apenas um marco legal, o CF de 1965 (cenário “1965”), enquanto o segundo incluiu a Lei Federal de proteção ao Cerrado de 1989 (cenário "1965/89"). O cenário "1965" reduz os déficits de RL em 49\% quando comparado ao cenário de base, dispensando os proprietários de terra da obrigação de restaurar ou recompor 423 mil hectares (kha) de VN. O cenário “1989/65" dispensa da obrigação de restauração ou recomposição 507 kha de $\mathrm{VN}$, representando uma redução de 59\% do déficit de RL em comparação ao cenário base. A redução apresentada pelo cenário "1965/89” assume grande importância uma vez que se concentra em áreas de Cerrado, bioma já extremamente fragmentado e impactado. Em conjunto com as reduções promovidas por outros Artigos da LPVN, estes efeitos revelam grande preocupação sobre o papel das RL como uma ferramenta para a conservação de VN em terras privadas, ameaçando compromissos governamentais de restauração e indicando que estratégias de comando e controle deverão ser complementadas por políticas de incentivo para atingir os objetivos de conservação desejados.

Palavras-chave: Vegetação Nativa, Conservação da Biodiversidade, Novo Código Florestal, Estado de São Paulo, Programa de Regularização Ambiental.

\section{Introduction}

Native vegetation (NV) on private land is worldwide recognized as essential for biodiversity conservation, climate regulation and maintenance of ecosystem services (Norton 2001, Doremus 2003, Tikka \& Kauppi 2003, Nunes et al. 2016). Strategies that balance NV conservation and economic activities, such as agriculture and animal production, are essential to involve landholders in conservation efforts (Harvey et al. 2008, Blom et al. 2010, Pacheco et al. 2017).

In Brazil, $54 \%$ of the remaining $\mathrm{NV}$ occurs in private lands (Sparovek et al. 2015). The "Native Vegetation Protection Law" (NVPL) (Brasil 2012) is the main national regulation for protecting NV on private land (Soares-Filho et al. 2014, Brancalion et al. 2016, Garcia et al. 2016). The NVPL replaced the previous Brazilian Forest Act (FA) (Brasil 1965) through a long process of disputes among multiple stakeholders until its approval by the National Congress in 2012 (Metzger et al. 2010, Nazareno et al. 2012, Sparovek et al. 2016). The NVPL's implementation is behind schedule after several delays of initially foreseen deadlines. For instance, the entering-step of the NVPL, the "Rural Environmental Registry" (Portuguese acronym: CAR), was postponed three times and, currently, landholders have until December 2019 to register to CAR and, this way, benefit from the "Environmental Regularization Program" (Portuguese acronym: PRA). PRA defines several rules that reduce protection of NV to promote easier compliance comparing the 2012 NVPL with the previous FA (1965). Some States have not defined the PRA regulations so far (SFB 2018).

The NVPL kept the Legal Reserve (LR) from the 1965's FA (Brasil 1965), one of the main mechanisms to foster conservation on private lands. LR corresponds to a land fraction of the farm for NV maintenance but allow NV sustainable management. Its size depends on the biome and the vegetation type, varying from 20 to $80 \%$ of the farm (Brasil 2012). LR areas have a crucial role in biodiversity conservation (Beca et al. 2017, Farah et al. 2017) and on the provision of environmental services, including water and soil protection, carbon storage, pollination, and agricultural pest control (Brancalion et al. 2016, Garcia et al. 2016,
Saturni et al. 2016, Librán-Embid et al. 2017, Oakleaf et al. 2017). Further, LR vegetation patches act as stepping-stones between public Protected Areas (Conservation Units). Since Brazilian Conservation Units are usually far from each other, the LR network is essential to functionally connect landscapes (Metzger 2001, Ribeiro et al. 2009, Tambosi et al. 2013).

However, the NVPL reduced substantially the total amount of protected NV in Brazil by granting partial amnesty for illegal deforestation prior to 2008 and allowing the reduction of the required LR in several situations (Brancalion et al. 2016). Previous studies suggested that NVPL reduced 37 Mha of LR total area (Sparovek et al. 2012, Freitas et al. 2017, Guidotti et al. 2017). Those estimations did not consider the controversial Article 68 (Art.68), which promotes additional LR reduction. Art.68 specifies that if the $\mathrm{NV}$ was converted without offending the legislation effective at the time of the conversion, the landholder should be waived from LR obligation. The effects of Art.68 are still unknown and may represent a huge cutback in NV protection, mainly in areas of long-established agricultural production, therefore also more degraded. Art.68 effects, consequently, may represent a major threat to the maintenance of ecosystem services and biodiversity protection. Further, knowing the effects of Art.68 over LR deficits may guide States strategies for the "Program for Recovery of Degraded Areas" (Portuguese acronym: PRADA), another requirement from the NVPL. It can drive, for example, polices to promote LR compensation enabling a market for the trade of NV surpluses that also result in additional environmental protection (May et al. 2015).

We developed a model to estimate the potential effects of Art.68 on LR using São Paulo State, Brazil, as a case study. São Paulo represents an extreme situation of a State with a long history of consolidated agriculture and early deforestation, what turns it into a valuable proxy of Art.68 maximum effects. Similar conditions would apply to other long-time consolidated agriculture areas in South, Southeast, and part of Central West Brazilian regions (Barretto et al. 2013). We considered two scenarios of law interpretation and application. For this, we analyzed the 
historical development of the Brazilian environmental legislation and identified periods in which accurate spatial data of $\mathrm{NV}$ were available.

\section{Material and Methods}

The effects of Art.68 were determined in two steps. First, the percentage of NV in 2008 was determined for each farm and checked against the LR requirement of the NVPL in São Paulo State (i.e., 20\%). The 2008 benchmark refers to the date set by the NVPL to exempt of restoration requirements or offsetting deforestation in disagreement with the $1965^{\prime}$ 'FA. If this percentage was not reached, the farm was considered as non-compliant and potentially eligible to access Art.68 benefits. In a second step, the model verified if the percentage of past NV decreased between the chosen legal benchmark and 2008. If a reduction was observed, the farm loses the Art. 68 benefit and the LR deficit was considered to be the same computed for 2008 (described in the first step). If no reduction was observed, the farm was considered eligible to access Art.68 benefit and LR deficit was computed as the area of 1965 NV subtracted by the area of 2008 NV.

The model takes into account that "Areas of Permanent Protection" (APP); i.e. areas that protect fragile environments such as hill tops, steep slopes and riparian forests; can be computed into the LR percentage as established by the NVPL. A detailed description of the modeling procedure and the combination with previous NVPL models is described in Supporting Informantion (Tables S1, S2, S3). It is also important to note that the model does not include farms smaller than four Fiscal Modules (FM) since NVPL discharge them from LR restoration. In São Paulo State, each FM varies from 5 to 40 ha (INCRA, 2013).

To model Art.68 we first analyzed previous environmental laws to identify key periods in which the minimal requirements for NV preservation in private lands had changed. This step was also important to determine the spatial scope of $\mathrm{NV}$ protection of past legislation. A second step was to search for past spatial data on NV cover with sufficient accuracy for each legal benchmark. Finally, we matched historical NV preservation requirements with historical spatial data on NV cover, creating two scenarios for Art.68 application and one baseline scenario.

\section{Native vegetation spatial data availability and previous preservation requirements}

Brazilian legal requirements for NV preservation in private lands changed over time, determining different levels of protection through LR (Table 1). The processes of checking the spatial scope of such legislation was ambiguous by the various terminologies and definitions used to describe NV over time (e.g. "matta", "arvoredo"). These differences lead to several possible legal interpretations about the past legislation amplitude. For instance, it is possible to interpret that all NV types, or that only the forested ones, were protected in the legislations previous to 1989 .

Our search for past NV cover databases showed that the first spatial data with the necessary accuracy and precision for the NVPL modeling was generated in the 1960s. This database consists of maps made by the "Brazilian Institute of Geography and Statistics" (IBGE) at the scale 1:50,000 (IBGE 1965). Thus, we do not have a spatial solution for NVPL spatial explicit modeling of Art.68 before the 1965's FA. To estimate Art.68 effects for previous laws, it would be necessary to rely on spatial equation models (Dias et al. 2016) and, by these, move from a spatial explicit solution to a still comprehensive, but probabilistic approach. Another option would be to keep the spatial explicit approach but narrow it to spatial data documents that are not comprehensively available, such as old farms' sketches, in some cases only available in old registry office books. In the first case, we would not reach the accuracy to access precise data for each farm, limiting this approach for implementation purpose by the responsible authority. Such a reference may be useful for regional planning or assessment, but improper for farm-level decisions. For the second, we would depend on one-by-one document analysis, where available, that would result in a partial and very time-consuming approach impossible to be applied for the whole State in a modelling research project.

Therefore, we adopted the 1965's Brazilian FA as the initial legal benchmark, disregarding all previous laws, and addressing the study with a spatial explicit large-scale model solution. The FA from 1965 (Federal Law 4.771/1965) introduces the term "Legal Reserve" for the first time and changes the percentage of protected NV to $20 \%$. Again, the interpretation about the comprehensiveness of NV protection given by the law is subjective, being uncertain if the protection applies to all physiognomies of $\mathrm{NV}$ or only to the forest types.

This outcome has a critical effect over São Paulo State "Environmental Regularization Program" (PRA) (São Paulo 2015). The State legislation indicates that in 1934, farms should keep as LR at least $25 \%$ of the existing forests. However, there is no precise spatial information on land cover available for 1934. The manual analysis based on information supplied by landholders may delay even more the implementation of the NVPL in the State, foster juridical queries and legal contests. Further, it could open an over-the-counter one by one negotiation opportunity that favors interpretation errors, administrative misconduct, and corruption. Other Brazilian States that are still deciding on how to define Art.68 interpretation rules for their PRAs should take into account the availability of accurate spatial data on the past NV cover in order design rules that allows a precise and systematic solution for the Art. 68 application.

In one of the scenarios we included the Federal Law from 1989 (Federal Law 7.803/1989) that complements the 1965 FA and reassures the protection of a $20 \% \mathrm{LR}$ area for farms located in Cerrado regions.

\section{Scenarios for Article 68 application}

We considered two scenarios to access the effects of Art. 68 over LR deficit in SP: scenario "1965" and scenario "1965/89", plus a baseline scenario to control for such effects (Table 2). The baseline scenario includes LR reduction mechanisms that were modeled by previous studies and based in other articles of the NVPL (i.e. Art. 13, 15 and 67) but do not account for the effects of Art.68 (Sparovek et al. 2012, 2015, Freitas et al. 2017, 2016). This scenario represents a control to isolate the effects of these two possible Art.68's interpretation rules.

For the scenario "1965", we considered a single legal benchmark: the 1965 Brazilian FA (Table 1), acknowledging that LR requirements were applied to all types of NV and, consequently, since 1965, NV outside APPs should represent at least $20 \%$ of the farm (Table 2).

For the scenario named "1965/89", we used two legal benchmarks: the Brazilian FA from 1965, and the 1989 Cerrado's protection Federal law (Law $\left.{ }^{\circ} 7.803 / 1989\right)$ (Table 1). In this scenario, farms with forested types of NV should comply with a 20\% LR since 1965 and, for other 
Tavares, P.A. et al.

Table 1. Brazilian main native vegetation protection mechanisms related to Article's 68 modeling and availbilty of accurate spatial data.

\begin{tabular}{|c|c|c|c|}
\hline Regulation & Year & Description & Data \\
\hline $\begin{array}{l}\text { São Paulo State } \\
\text { Law } 2.223\end{array}$ & 1927 & $\begin{array}{l}\text { Sets the São Paulo State Forest Service and establishes that properties with vegetation and larger } \\
\text { than } 100 \text { ha must keep a forest cover over } 10 \% \text { of its area, except when it is homogeneous vegetation } \\
\text { ("mattas" in the Portuguese original) or vegetation with spontaneous regrowth (Art. 5). }\end{array}$ & no \\
\hline $\begin{array}{l}\text { Federal Decree } \\
23.793\end{array}$ & 1934 & $\begin{array}{l}\text { First Brazilian Forest Act. Compels landholders to protect } 25 \% \text { of the vegetation present in the property } \\
\text { ("mattas" in the Portuguese original) (Art. 23). }\end{array}$ & no \\
\hline $\begin{array}{l}\text { Federal Law } \\
4.771\end{array}$ & 1965 & $\begin{array}{l}\text { Second Brazilian Forest Act. Establishes different percentages of native vegetation protection } \\
\text { accordingly to the region where the property is located. Landholders from the southeast, south and } \\
\text { central-west Brazilian regions of the country must protect } 20 \% \text { of forests and other forms of native } \\
\text { vegetation in their lands (Art. 16). }\end{array}$ & yes \\
\hline $\begin{array}{l}\text { São Paulo State } \\
\text { Decree } 49.141\end{array}$ & 1967 & $\begin{array}{l}\text { Sets the protection of } 20 \% \text { for a specific Cerrado vegetation type ("Cerradão", in the Portuguese } \\
\text { original) (Art. 7). }\end{array}$ & yes \\
\hline $\begin{array}{l}\text { Federal Law } \\
7.803\end{array}$ & 1989 & $\begin{array}{l}\text { Changes the Law } 4.771 / 1965 \text { and reassures the protection of a } 20 \% \text { Legal Reserve for Cerrado areas } \\
\text { (Art. 16). }\end{array}$ & yes \\
\hline $\begin{array}{l}\text { Federal Law } \\
11.428\end{array}$ & 2006 & Atlantic Forest Protection Law. Sets special protection mechanisms for the Atlantic Forest biome. & yes \\
\hline $\begin{array}{l}\text { Federal Decree } \\
6.514\end{array}$ & 2008 & $\begin{array}{l}\text { Environmental infractions decree. Benchmark used by the Law } 12.651 / 2012 \text { as a cutting line to stablish } \\
\text { differences in conservation and restoration requirements for Areas of Permanent Preservation and Legal } \\
\text { Reserves. }\end{array}$ & yes \\
\hline $\begin{array}{l}\text { Federal Law } \\
12.651\end{array}$ & 2012 & $\begin{array}{l}\text { Third Brazilian Forest Act named "Native Vegetation Protection Law". } \\
\text { Sets the Legal Reserve limits of } 80 \% \text { for forests, } 35 \% \text { for "Cerrado" and } 20 \% \text { for "Campos Gerais" } \\
\text { inside the Legal Amazon Boundaries and } 20 \% \text { for other biomes (Art. 12). Establishes several Legal } \\
\text { Reserve reduction mechanisms (Art. 12, 13, 15, } 67 \text { and } 68 \text { ). }\end{array}$ & yes \\
\hline
\end{tabular}

Table 2. Description of the main requirements and data used to perform the three considered scenarios of Article 68 implementation.

\begin{tabular}{|c|c|c|c|}
\hline Scenario & Past Native Vegetation database & Native Vegetation classification & Legal Reserve requirements \\
\hline Baseline & n.a. ${ }^{1}$ & n.a. ${ }^{1}$ & Compliance in 2008 with the NVPL \\
\hline 1965 & 1:50000 IBGE maps ${ }^{2}$ & n.a. ${ }^{1}$ & $\begin{array}{l}\text { NV outside APP } \geq 20 \% \text { since } 1965 \\
\text { Compliance in } 2008 \text { with the NVPL }\end{array}$ \\
\hline $1965 / 89$ & 1:50000 IBGE maps ${ }^{2}$ & RADAM Project maps ${ }^{3}$ & $\begin{array}{l}\text { NV outside APP } \geq 20 \% \text { since } 1965 \text { for forested NV } \\
\text { NV outside APP } \geq 20 \% \text { since } 1989 \text { for other types of NV } \\
\text { Compliance in } 2008 \text { with the NVPL }\end{array}$ \\
\hline
\end{tabular}

Notes: ${ }^{1}$ n.a. $=$ does not apply; ${ }^{2}$ IBGE, $1965 ;{ }^{3}$ IBGE, 2015.

types of NV, with more open canopies such as savannahs (all Cerrado vegetation types, excluding the "Cerradão", which was considered as a forested vegetation) or grasslands (Campo) should comply with a $20 \%$ LR only after 1989. To identify the type of NV in each farm we used maps from the RADAM Brasil project (IBGE 2015) and classified it as "forested NV" or "other types of NV".

For scenarios "1965" and "1965/89", we used the legal interpretation which states that landholders who, at some time, have not complied with the law in force, lose the benefits from Art.68, demanding 20\% of LR at current time.

These two scenarios represent the two most common interpretations of the 1965 and 1989 legal references, being the "1965/89" scenario in line with the State PRA (São Paulo 2015) and the "1965" scenario, that is more protective, in line with the interpretation of the environmental Civil Society and Public Attorney agencies (Loubet 2014, Chiavari \& Lopes 2016).

\section{Results and Discussion}

\section{São Paulo State LR deficits}

For all three scenarios, LR deficits were unevenly distributed among São Paulo State, with a higher concentration at West, Northwest and Mid-West regions (Figures 1, 2 and 3). The "baseline" scenario created a total LR deficit of 865 thousand hectares (kha) (Figure 1), of which 635 kha were located at Atlantic Forest and 230 kha in the Cerrado biome (Table 3).

Scenario " 1965 " reduced LR deficits in almost 50\% in relation to the baseline scenario, waiving landholders from restoration needs in 423 kha (Figure 2). Scenario "1965/89" reduced additional 84 kha from restoration needs when compared to scenario "1965", a 59\% reduction in the LR deficit in relation to the baseline scenario (Figure 3).

The reduction in LR brought about by scenario "1965/89" was particularly important because the geography of the additional reduction 
Legal Reserves cutbacks

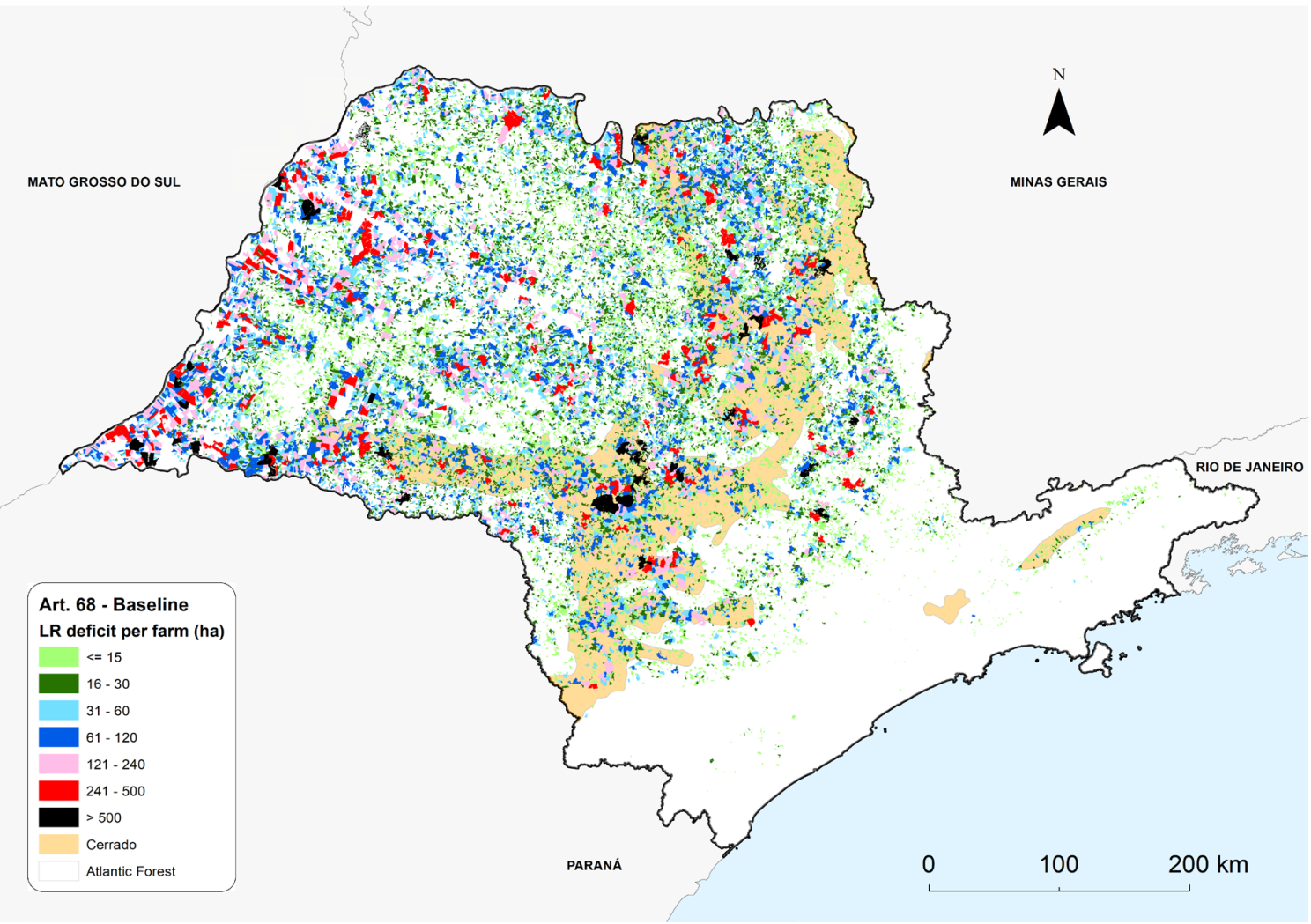

Figure 1. São Paulo State Legal Reserve deficits per farm, in hectares, for the baseline scenario (i.e. without art. 68 inclusion), total deficit of 865 thousand hectares from a total of 30,417 farms with deficit. Each polygon represents one farm.

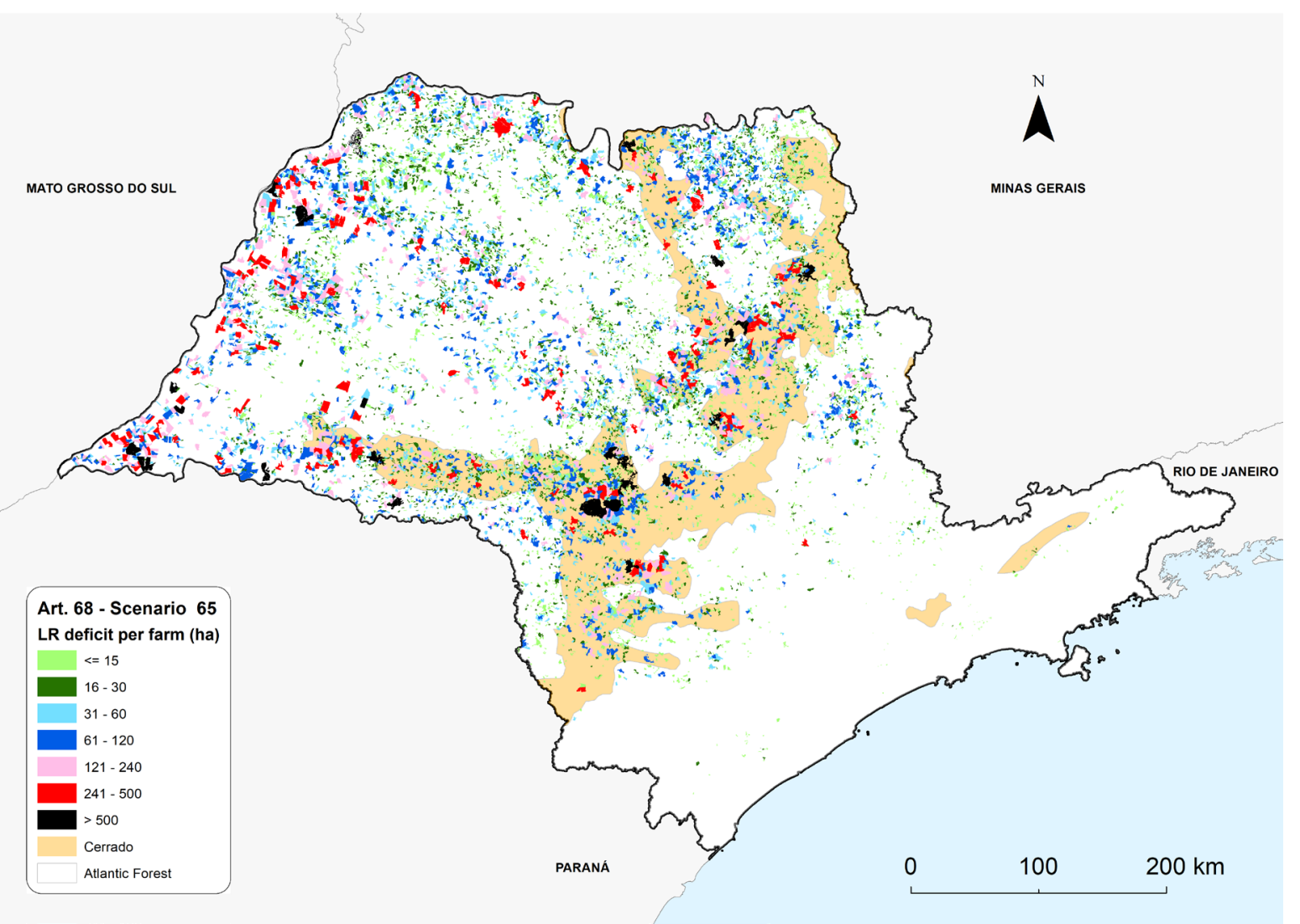

Figure 2. São Paulo State Legal Reserve deficits per farm, in hectares, for the scenario 1965, total deficit of 443 thousand hectares from a total of 12,324 farms with deficit. Each polygon represents one farm. 


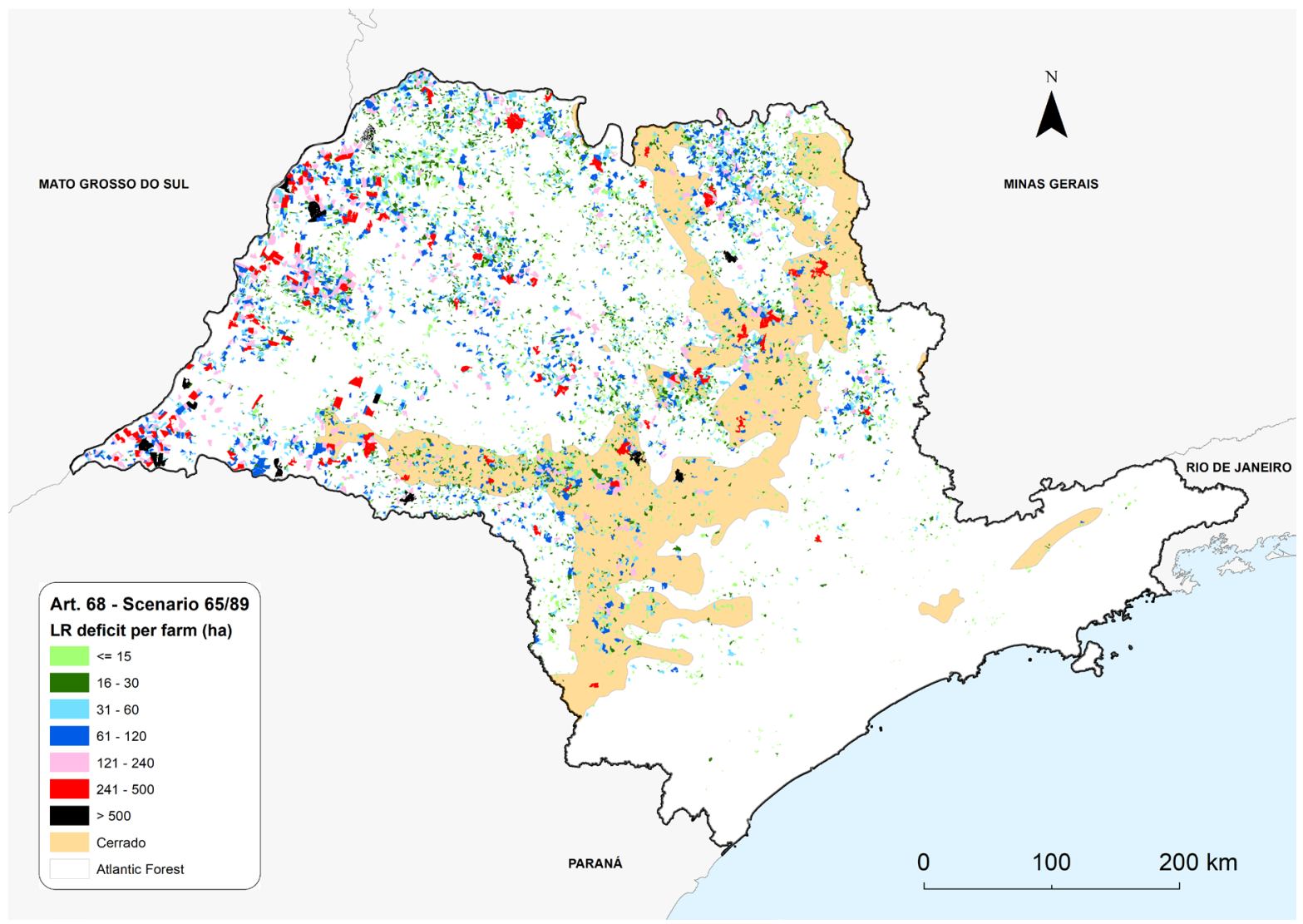

Figure 3. São Paulo State Legal Reserve deficits, hectare, for the "1965/89" scenario, total deficit of 358 thousand hectares from a total of 10,477 farms with deficit. Each polygon represents one farm.

Table 3. Legal Reserve deficit and native vegetation surplus in thousand hectares (kha), for the three considered scenarios.

\begin{tabular}{lcc}
\hline $\begin{array}{l}\text { Native Vegetation } \\
\text { Surplus }^{1} \text { (kha) }\end{array}$ & \multicolumn{2}{c}{ Legal Reserve Deficit (kha) Scenario } \\
\cline { 2 - 3 } 776 & Baseline & $\mathbf{1 9 6 5}$ \\
119 & 635 & 294 \\
895 & 230 & 149 \\
\hline
\end{tabular}

Note: ${ }^{1}$ Native Vegetation (NV) surplus accounts for the total amount of NV available for LR offsetting, including large farmlands (more than 4 Fiscal Modules) with more than $20 \%$ of NV and any existing NV fragments in small properties (less than 4 Fiscal Modules).

occurs on the Cerrado biome (Figure 4). While the implementation of Art.68, considering scenario " $1965 / 89$ ", reduced the LR deficit in only $4 \%$ for Atlantic Forest, it reduced by $50 \%$ LR deficit in the Cerrado biome in SP (Table 3). The difference between both scenarios ("1965" and "1965/89") can be explained by the fact that scenario " $1965 / 89$ " adds a second legal benchmark to the model. In this scenario, for forested NV types, the model follows the 1965's FA (Brasil 1965), for other NV types, it follows the Cerrado's protection law (Brasil 1989). Thus, suppression of non-forested NV between 1965 and 1989, more common in the Cerrado biome, was exempted from LR restoration or offsetting to the percentage required by the NVPL in scenario " $1965 / 89$ " (Brasil 2012).
In this period $\mathrm{NV}$ was converted mainly for sugarcane plantations, which was expanding quickly in the region, boosted by incentives given through the "National Alcohol Program" (Pró-Alcool) (Bastos 2007, Natale Netto 2007, Camara \& Caldarelli 2016). By that time, driven by favorable soil and climate conditions, sugarcane expanded over a large extent of Cerrado NV, increasing deforestation rates at this biome (Durigan et al. 2004, Kronka et al. 2005, Takaaki et al. 2015). Considering that Cerrado has a remarkable low occurrence of protection through Conservation Units - 24 Sustainable Use Conservation Units, representing a total area of 433.674 ha; while Atlantic Forest has 142, representing a total area of 3.412.517 ha (DATAGEO 2018) - the exemption of restoration or offsetting of non-forested $\mathrm{NV}$ can have a negative impact over the conservation of this already very fragmented biome (Durigan et al. 2007, Strassburg et al. 2017). Presumably, this effect will also occur in other Brazilian States that had a similar history of agriculture development (e.g. Paraná, South of Minas Gerais, South of Mato Grosso do Sul).

\section{São Paulo State native vegetation surplus}

According to the NVPL, LR deficits may be restored within non-compliant farms or offset in another farm with NV surplus in the same biome. Presumably, most farmers will opt for offsetting to avoid the conversion of productive farmland to nature protection or the costs with a restoration plan (Bernasconi et al. 2016, Freitas et al. 2017). 


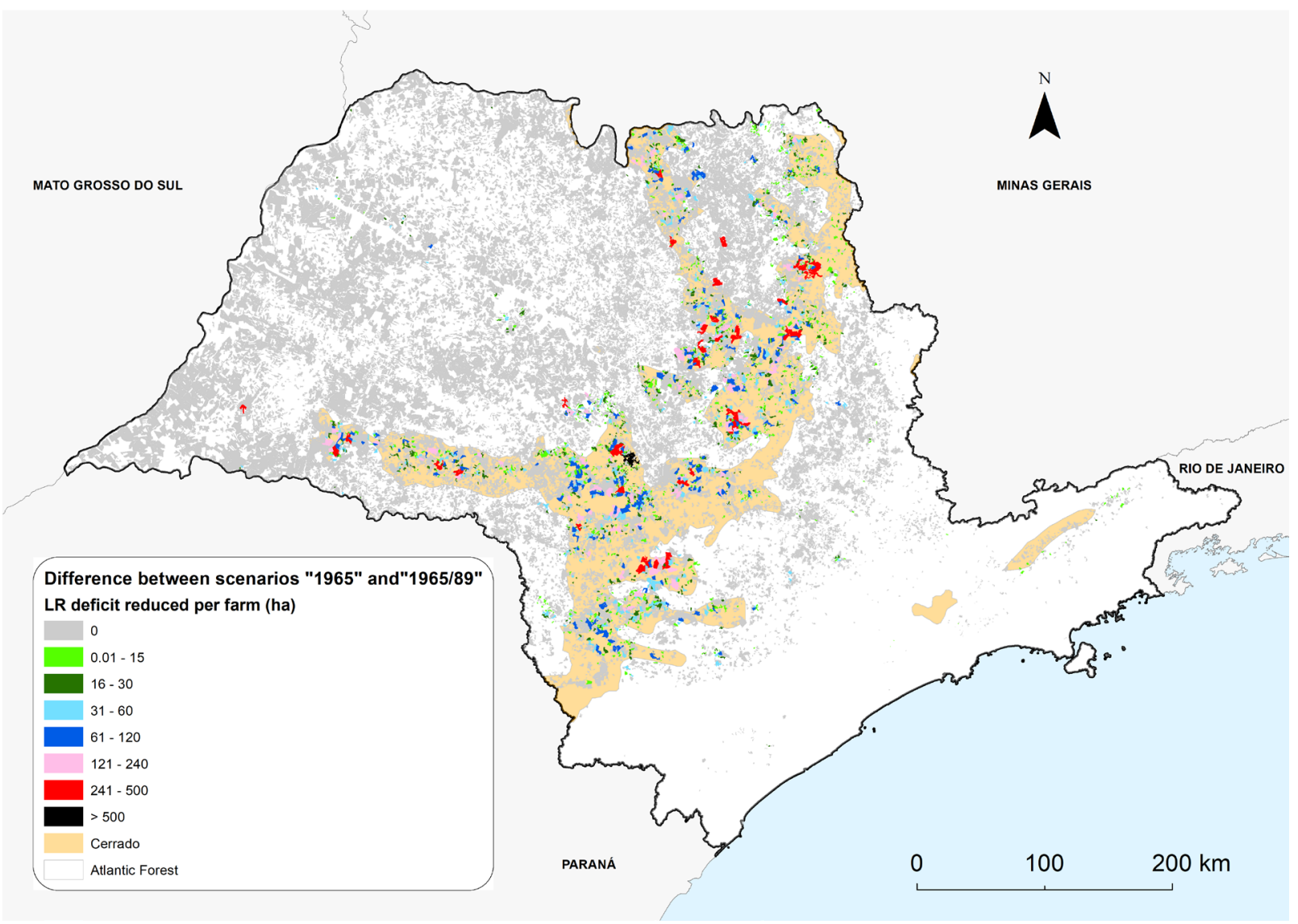

Figure 4. São Paulo State Legal Reserve deficits, diference between scenarios “1965” and "1965/89". Each polygon represents one farm.

In the Atlantic Forest, for scenarios " 1965 " and "1965/89", the available NV for offsetting-NV surplus - was substantially higher than the LR total deficits (Table 3). This means that the entire LR deficit in the Atlantic Forest could be offset within the State without the need for $\mathrm{NV}$ restoration or conversion of productive lands. On the other hand, for Cerrado, only for scenario " $1965 / 89$ " it would be possible to overcome the need for NV restoration or conversion of productive land.

However, since both biomes are already protected by NV conservation laws (São Paulo 1967, Brasil 2006), LR offsetting would not lead to additionality in nature protection. Thus, in order to increase NV conservation and the supply of ecosystem services, the only scenario that promoted these by legal enforcement was scenario "1965" and restricted to the Cerrado biome. For scenario " $1965 / 89$ " it is essential to promote incentives for NV restoration, such as payments for environmental services (PES) and other policies to foster restoration of $\mathrm{NV}$ on private land or the creation of public owned Conservation Units.

\section{Conclusions}

We could not identify an accurate model solution for Art. 68 before 1965. The suggested solutions allow systematic analysis of Art. 68 reducing legal contests and the negative effects of subjectivity in the one-by-one analysis by governmental officials. Since the spatial data we used for 1965 NV cover in São Paulo State was based on the first nationwide aero photographs, we believe this is also the earliest date for other Brazilian States. Thus, any attempt to apply Art.68 before the 1965 's Brazilian FA, e.g. the 1934 FA (Brasil 1934) would have to rely on probabilistic NV maps or one-by-one manual analysis of data provided by the landholders. These options would challenge the development of a large-scale and accurate tool for decision making to be used by governmental agencies during the implementation phase of the NVPL. This fact should be considered for Art.68 definition in the States PRAs, to avoid the undesired effects of unrealistic legal rules that undermine the applicability of the NVPL.

Regarding the effects of Art.68 it decreased the LR deficits between $49 \%$ and $59 \%$. This effect adds substantially to the already important reductions caused other rules from the NVPL (Freitas et al. 2016), unfolding great concerns on the role of LR as a conservation aid for NV preservation on private land. Furthermore, we observed a higher LR deficit reduction in areas of Cerrado biome changing from scenario " 1965 " to "1965/89". This biome had high deforestation rates in the past and has only a small amount of land protected by public Conservation Units.

It is very likely that the trends observed in São Paulo also apply to other States with a long history of agricultural occupation (e.g. South Region, Minas Gerais, South of Mato Grosso do Sul). In such conditions, the enforcement capacity of command and control mechanisms to promote NV preservation on private land outside APPs is currently largely overestimated by modeling due to the absence of Art. 68 effects. 
In order to keep the benefits of NV restoration, the command and control approach should be complemented by incentive policies. The assessment of NVPL effects on NV conservation and the planning of NVPL implementation could substantially benefit from a national wide modelling of the effects of Art.68.

\section{Supplementary material}

The following online material is available for this manuscript:

Table S1 - Datasets used to generate São Paulo State land tenure and boundaries map.

Table S2 - Datasets used to spatialize and classify past NV cover in the state of São Paulo.

Table S3 - Possibilities of native NV cover at the propriety (in \%) along legal benchmarks and applicability of Article 68 (Federal Law $n^{\circ} 12.651 / 2012$ ) benefits.

\section{Acknowledgments}

This research was supported by São Paulo Research Foundation Fapesp (2016/17680-2; 2017/02755-0; 2017/07942-2); and World Wide Fund for Nature Brazil - WWF. The research is part of the program BIOTA Fapesp. JPM was funded by the Brazilian National Council for Scientific and Technological Development. RRR was funded by Fapesp (Fapesp 2013/50718-5). We are very grateful for all the help and hard work of the GIS staff from Imaflora and Agrosatélite. We appreciate the comments and suggestions from the anonymous reviewers which helped us to improve the manuscript.

\section{Author Contributions}

Paulo André Tavares: substantial contribution in the concept and design of the study; contribution to data collection; contribution to data analysis and interpretation and contribution to manuscript preparation.

Alice Dantas Brites: substantial contribution in the concept and design of the study; contribution to manuscript preparation; contribution to data analysis and contribution to critical revision, adding intellectual content.

Gerd Sparovek: substantial contribution in the concept and design of the study; contribution to data collection; contribution to data analysis and interpretation and contribution to manuscript preparation.

Vinícius Guidotti: contribution to data analysis and interpretation and contribution to critical revision, adding intellectual content.

Felipe Cerignoni: contribution to data analysis.

Daniel Aguiar: contribution to data collection and contribution to data analysis and interpretation.

Jean Paul Metzger: substantial contribution in the concept and design of the study and contribution to critical revision, adding intellectual content

Ricardo Ribeiro Rodrigues: substantial contribution in the concept and design of the study and contribution to critical revision, adding intellectual content.

Luís Fernando Guedes Pinto: contribution to critical revision, adding intellectual content.
Kaline de Mello: substantial contribution in the concept and design of the study and contribution to critical revision, adding intellectual content.

Paulo Guilherme Molin: contribution to data analysis and interpretation and contribution to critical revision, adding intellectual content.

\section{Conflicts of interest}

The authors declare that they have no conflict of interest related to the publication of this manuscript.

\section{References}

ANDRADA E SILVA, J. 1821. Lembranças e Apontamentos do Governo Provisorio para os Senhores Deputados da Provincia de São Paulo.

BARRETTO, A.G.O.P., BERNDES, G., SPAROVEK, G. \& WIRSENIUS, S. 2013. Agricultural intensification in Brazil and its effects on land-use patterns: an analysis of the 1975-2006 period. Glob. Change Biol. 19(6): $1804-1815$.

BASTOS, V.D. 2007. Etanol, alcoolquímica e biorrefinarias. BNDS, Rio de Janeiro.

BECA, G., VANCINE, M., CARVALHO, C., PEDROSOA, F., ALVES, R., BUSCARIOL, D., PERES, C., RIBEIRO, M. \& GALETTI, M. 2017. High mammal species turnover in forest patches immersed in biofuel plantations. Biol. Conserv. 210(Part A): 352-359.

BERNASCONI, P., BLUMENTRATH, S., BARTON, D.N., RUSCH, G.M. \& ROMEIRO, A.R. 2016. Constraining Forest Certificate's Market to Improve Cost-Effectiveness of Biodiversity Conservation in São Paulo State, Brazil. Plos One 11(10): 1-18.

BLOM, B., SUNDERLAND, T. \& MURDIYARSO, D. 2010. Getting REDD to work locally: lessons learned from integrated conservation and development projects. Environ. Science \& Policy 13(2): 164-172.

BRANCALION, P.H.S., GARCIA, L.C., LOYOLA, R., RODRIGUES, R.R., PILLAR, V.D. \& LEWINSOHN, T.M. 2016. A critical analysis of the Native Vegetation Protection Law of Brazil (2012): Updates and ongoing initiatives. Nat. Conservação 141-15.

BRASIL. 1934. Decreto no 23.793. de 23 de janeiro de 1934. Brasil.

BRASIL. 1965. Lei no 4.771, de 15 de setembro de 1965. Brasília.

BRASIL. 1989. Lei no 7.803, de 18 de julho de 1989. Brasília.

BRASIL. 2006. Lei no 11.428, de 22 de dezembro de 2006. Brasília.

BRASIL. 2012. Lei no 12.651, de 25 de maio de 2012. Brasília.

BRITO, B. 2017. Potential trajectories of the upcoming forest trading mechanism in Pará State, Brazilian Amazon. Plos One 12(4): 1-21.

CAMARA, M.R.G. da \& CALDARELLI, C.E. 2016. Expansão canavieira e o uso da terra no estado de São Paulo. Estud. Av. 30: 93-116.

CHIAVARI, C. \& LOPES, L.C. 2016. Os caminhos para a regularização ambiental: decifrando o Novo Código Florestal. In Mudanças no Código Florestal brasileiro: desafios para a implementação da nova lei (A. P. da Silva, H. R. Marques, \& R. H. R. Sambuichi, eds) IPEA, Rio de Janeiro, p.21-44.

DATAGEO 2018. http://datageo.ambiente.sp.gov.br/ (último acesso em $13 / 09 / 2018)$

DIAS, L.C.P., PIMENTA, F.M., SANTOS, A.B., COSTA, M.H. \& LADLE, R.J. 2016. Patterns of land use, extensification, and intensification of Brazilian agriculture. Glob. Change Biol. 22(8): 2887-2903.

DOREMUS, H. 2003. A policy portfolio approach to biodiversity protection on private lands. Environ. Science \& Policy 6(3): 217-232.

DURIGAN, G., FRANCO, G.A.D. \& SIQUEIRA, M.F. 2004. A vegetação dos remanescentes de Cerrado no Estado de São Paulo. In Viabilidade dos remanescentes de Cerrado no Estado de São Paulo (M. D. Bitencourt \& R. R. Mendonça, eds) Annablume, FAPESP, São Paulo, p.29-56. 
DURIGAN, G., SIQUEIRA, M.F. de \& FRANCO, G.A.D.C. 2007. Threats to the Cerrado remnants of the state of São Paulo, Brazil. Sci. Agr. 643: 55-363.

FARAH, F., MUYLAERT, R., RIBEIRO, M., RIBEIRO, J., MANGUEIRA, J., SOUZA, V. \& RODRIGUES, R. 2017. Integrating plant richness in forest patches can rescue overall biodiversity in human-modified landscapes. Forest Ecol. Manag. 397: 78-88.

FREITAS, F., SPAROVEK, G., MÖRTBERG, U., SILVEIRA, S., KLUG, I. \& BERNDES, G. 2017. Offsetting legal deficits of native vegetation among Brazilian landholders: Effects on nature protection and socioeconomic development. Land Use Policy 68: 189-199.

FREITAS, F.L., SPAROVEK, G. \& MATSUMOTO, M. 2016. A adicionalidade do mecanismo de compensação de reserva legal da lei no $12.651 / 2012$ : uma análise da oferta e demanda de cotas de reserva ambiental. In Mudanças no Código Florestal brasileiro: desafios para a implementação da nova lei (A. Silva, H. Marques, \& R. Sambuichi, eds) IPEA, Rio de Janeiro, p. 125-158.

GARCIA, L.C., ELLOVITCH, M. da F., RODRIGUES, R.R., BRANCALION, P.H.S., MATSUMOTO, M.H., GARCIA, F.C., LOYOLA, R. \& LEWINSOHN, T.M. 2016. Análise científica e jurídica das mudanças no Código Florestal, a recente Lei de Proteção da Vegetação Nativa. ABECO, Rio de Janeiro.

GUIDOTTI, V., FREITAS, F.L.M., SPAROVEK, G., HAMAMURA, C., CERIGNONI, F. \& PINTO, L.F.G. 2017. Números detalhados do novo código florestal e suas implicações para os PRAs. Imaflora, Piracicaba.

HARVEY, C., OLIVER, K., ROBIN, C., G., F.B., BRYAN, F., M., G.D., MIGUEL, M., HELDA, M., RONALD, N., LORENA, S., MICHIEL, V.A.N.B. \& MARK, W. 2008. Integrating Agricultural Landscapes with Biodiversity Conservation in the Mesoamerican Hotspot. Conserv. Biol. 22(1): 8-15.

IBGE. 1965. Cartas Topográficas 1:50.000.

INCRA. 2013. Sistema Nacional de Cadastro Ambiental Rural. http://www. incra.gov.br/sites/default/files/uploads/estrutura-fundiaria/regularizacaofundiaria/indices-cadastrais/indices_basicos_2013_por_municipio.pdf (último acesso em 25/06/2019).

KRONKA, F.J.N., NALON, M.A., MATSUKUMA, C.K., LIMA, M.P., GUILLAUMON, J.R., BAITELLO, J.B., BORGO, S.C., MANETTI, L.A., BARRADAS, A.M.F., FUKUDA, C., SHIDA, C.N., BARBOSA, O., SOARES, A.P., JOLY, C.A. \& COUTO, H.T. 2005. Inventário Florestal da Vegetação Natural do Estado de São Paulo. Secretaria do Meio Ambiente; Instituto Florestal, Imprensa Oficial, São Paulo.

LIBRÁN-EMBID, F., DE COSTER, G. \& METZGER, J.P. 2017. Effects of bird and bat exclusion on coffee pest control at multiple spatial scales. Landscape Ecol. 32(9): 1907-1920.

LOUBET, L.F. 2014. Análise histórica do instituto da reserva legal. 761-19.

METZGER, J.P. 2001. Effects of deforestation pattern and private nature reserves on the forest conservation in settlement areas of the Brazilian Amazon. Biota Neotrop. 11-14.

METZGER, J.P., LEWINSOHN, T.M., JOLY, C.A., VERDADE, L.M., MARTINELLI, L.A. \& RODRIGUES, R.R. 2010. Brazilian Law: Full Speed in Reverse? Science 329(5989): 276-277.

NATALE NETTO, J. 2007. A saga do álcool. Novo Século. Novo Século, São Paulo.

NAZARENO, A.G., FERES, J.M., DE CARVALHO, D., SEBBENN, A.M., LOVEJOY, T.E. \& LAURANCE, W.F. 2012. Serious New Threat to Brazilian Forests. Conserv. Biol. 26(1): 5-6.

NORTON, A.D. 2001. Conservation Biology and Private Land: Shifting the Focus. Conserv. Biol. 14(5): 1221-1223.
NUNES, S., GARDNER, T., BARLOW, J., MARTINS, H., SALOMÃO, R., MONTEIRO, D. \& SOUZA, C. 2016. Compensating for past deforestation: Assessing the legal forest surplus and deficit of the state of Pará, eastern Amazonia. Land Use Policy 57: 749-758.

OAKLEAF, J.R., MATSUMOTO, M., KENNEDY, C.M., BAUMGARTEN, L., MITEVA, D., SOCHI, K. \& KIESECKER, J. 2017. LegalGEO: Conservation tool to guide the siting of legal reserves under the Brazilian Forest Code. Appl. Geogr. 86: 53-65.

PACHECO, P., PIKETTY, M.G., POCCARD-CHAPUIS, R., GARCIA-DRIGO, I., EL HUSNY, J.C., GOMES, M. \& TOURRAND, J.-F. 2017. Beyond zero deforestation in the Brazilian Amazon: Progress and remaining challenges to sustainable cattle intensification. CIFOR, Bogor.

RIBEIRO, M.C., METZGER, J.P., MARTENSEN, A.C., PONZONI, F.J. \& HIROTA, M.M. 2009. The Brazilian Atlantic Forest: How much is left, and how is the remaining forest distributed? Implications for conservation. Biol. Conserv. 142(6): 1141-1153.

SÃO PAULO. 1967. Decreto ${ }^{\circ} 49.141$ de 28 de dezembro de 1967. São Paulo. SÃO PAULO. 2015. Lei no 15.684 , de 14 de janeiro de 2015. São Paulo.

SATURNI, F.T., JAFFÉ, R. \& METZGER, J.-P. 2016. Landscape structure influences bee community and coffee pollination at different spatial scales. Agr. Ecosyst. Environ. 235(1): 1-12.

SILVA, J.S. da \& RANIERI, V.E.L. 2014. O mecanismo de compensação de reserva legal e suas implicações econômicas e ambientais. Ambient. Soc. 17(1): $115-132$.

SOARES-FILHO, B., RAJÃO, R., MACEDO, M., CARNEIRO, A., COSTA, W., COE, M., RODRIGUES, H. \& ALENCAR, A. 2014. Cracking Brazil's Forest Code. Science 344(6182): 363-364.

SOARES-FILHO, B., RAJÃO, R., MERRY, F., RODRIGUES, H., DAVIS, J., LIMA, L.L., MACEDO, M., COE, M., CARNEIRO, A. \& SANTIAGO, L. 2016. Brazil's market for trading forest certificates. Plos One 11(4): 1-17.

SPAROVEK, G., ANTONIAZZI, L.B., BARRETTO, A., BARROS, A.C., BENEVIDES, M., BERNDES, G., DO PRADO BRAGA, E., CALMON, M., GROKE, P.H., DE AVELAR MARQUES, F.N., NOGUEIRA, M.P., GUEDES PINTO, L.F. \& PRECIOSO, V. 2016. Sustainable bioproducts in Brazil: disputes and agreements on a common ground agenda for agriculture and nature protection. Biofuels Bioprod. Bior. 10(3): 204-221.

SPAROVEK, G., BARRETTO, A.G.D.O.P., MATSUMOTO, M. \& BERNDES, G. 2015. Effects of Governance on Availability of Land for Agriculture and Conservation in Brazil. Environ. Sci. Technol. 49(17): 10285-10293.

SPAROVEK, G., BERNDES, G., BARRETTO, A.G. de O.P. \& KLUG, I.L.F. 2012. The revision of the Brazilian forest act: Increased deforestation or a historic step towards balancing agricultural development and nature conservation? Environ. Sci. Policy 16: 65-72.

STRASSBURG, B.B.N., BROOKS, T., FELTRAN-BARBIERI, R., IRIBARREM, A., CROUZEILLES, R., LOYOLA, R., LATAWIEC, A.E., OLIVEIRA FILHO, F.J.B., SCARAMUZZA, C.A. de M., SCARANO, F.R., SOARES-FILHO, B. \& BALMFORD, A. 2017. Moment of truth for the Cerrado hotspot. Nat. Ecol. Evol. 1, art. 0099.

TAKAAKI, N., HISAYOSHI, H. \& RICARDO, S. 2015. Characteristics of sugarcane production in the State of São Paulo, Brazil. Geographical Space 53-80.

TAMBOSI, L.R., MARTENSEN, A.C., RIBEIRO, M.C. \& METZGER, J.P. 2013. A Framework to Optimize Biodiversity Restoration Efforts Based on Habitat Amount and Landscape Connectivity. Restor. Ecol. 22(2): 169-177.

TIKKA, P.M. \& KAUPPI, P. 2003. Introduction to special issue: Protecting Nature on Private Land from Conflicts to Agreements. Environ. Sci. Policy 6(3): 193-194. 